\title{
Antarctic Surface Hydrology and Impacts on Ice Sheet Mass Balance
}

\author{
Robin E. Bell ${ }^{1}$, Alison F. Banwell ${ }^{2,3}$, Luke D. Trusel ${ }^{4}$ and Jonathan Kingslake ${ }^{1,5}$ \\ 1. Lamont-Doherty Earth Observatory, Columbia University, Palisades, NY, USA \\ 2. Scott Polar Research Institute, University of Cambridge, Cambridge, UK \\ 3. CIRES and NSIDC, University of Colorado Boulder, CO, USA \\ 4. Department of Geology, Rowan University, Glassboro, NJ, USA \\ 5. Department of Earth and Environmental Sciences, Columbia University, Palisades, NY, \\ USA
}

\begin{abstract}
Summary
Melting is pervasive along the ice surrounding Antarctica. On the surface of the grounded ice sheet and floating ice shelves, extensive networks of lakes, streams and rivers both store and transport water. As melting increases with a warming climate, the surface hydrology of Antarctica in some regions could resemble Greenland's present-day ablation and percolation zones. Drawing on observations of widespread Antarctica surface water and decades of study in Greenland, we consider three modes by which meltwater could impact Antarctic mass balance: increased runoff, meltwater injection to the bed, and meltwater-induced ice-shelf fracture, all of which may contribute to future ice sheet mass loss from Antarctica.
\end{abstract}

\section{1) Introduction}

Surface meltwater in Antarctica is more extensive than previously thought and its role in projections of future mass loss are becoming increasingly important. As accurately projecting future sea level rise is essential for coastal communities around the globe, understanding how surface melt may either trigger or buffer rapid changes in ice flow into the ocean is critical. We provide an overview of the current understanding of the major components of the Antarctic surface hydrology system and the distribution of melt. Using the framework of surface hydrology in Greenland, we consider the different ways in which surface hydrology can impact ice sheet mass balance. Looking to the future, we discuss how the hydrologic systems will evolve in Antarctica as well as their impact on future changes in ice sheet mass balance. Finally, we highlight knowledge gaps that limit our understanding of the impact of increased surface meltwater on future sea level rise.

\section{2) Current Distribution of Meltwater in Antarctica}

Meltwater on the surface of Antarctica was observed by early explorers who noted the noise of running water and water seeping into their tents ${ }^{1}$. Today the surface melt distribution in Antarctica (Figure 1) is determined using satellite observations ${ }^{2-5}$ and reanalysis-forced regional climate modeling ${ }^{6}$. The surface meltwater production estimates derived from these two methods correspond well with in situ observations ${ }^{7}$. Presently, the most intense melt is observed across ice shelves (Figure 1), particularly along the Antarctic Peninsula, including the Larsen C, Wilkins, and George VI ice shelves, as well 
as the relatively low-latitude East Antarctic ice shelves, including the West and Shackleton ice shelves. More localized, but relatively intense, melt occurs on other East Antarctic ice shelves, including the Amery and Roi Baudouin ice shelves ${ }^{7,8}$, where extensive surface hydrological networks develop. The two largest ice shelves, the Ross and Ronne-Filchner, experience only minor surface melting. The upper elevation limit of surface melting today is generally $\sim 1400 \mathrm{~m}$ during spatially extensive, but low magnitude, West Antarctic melt episodes, ${ }^{7,9}$, compared to $3200 \mathrm{~m}$ elevation limit in Greenland during the anomalous ${ }^{10} 2012$ melt events.

Liquid water on the Antarctic Ice Sheet and the floating ice shelves that buttress upstream grounded ice (Figure 1) is found in supraglacial lakes, subsurface lakes, surface streams and rivers ${ }^{1,8,11-14}$. Through-ice fractures are interpreted as evidence of water having drained through ice shelves (Figure 1a, 2) ${ }^{15}$. Similar to terrestrial hydrologic systems, these components of the Antarctic hydrologic system store, transport, and export water. In contrast to terrestrial hydrology, on ice sheets and glaciers water can refreeze with consequences for the temperature of the surrounding ice ${ }^{16-18}$, firn or snow. Storage occurs in lakes, crevasses, in buried lakes and possibly in firn aquifers. Transport and export are less persistent and more difficult to observe than lakes, streams and rivers $^{14,19,20}$. Antarctic surface and subsurface hydrological systems have been studied using satellite and airborne imagery ${ }^{1,8,11-14}$, although field-based observations are limited ${ }^{8,21-23}$.

\section{2a Surface Storage of Meltwater}

Meltwater is stored in surface lakes on both grounded and floating ice. On grounded ice, lakes develop in areas with local-scale melt enhancement and relatively low accumulation rates; areas that are often close to rock outcrops and blue ice (e.g. Shackleton Glacier; Figure 1j) ${ }^{12,14}$. Similar to Greenland ${ }^{20}$, on grounded Antarctic ice, lakes form in persistent surface depressions. Formation of surface lakes for decades in the same location is evidence for control by the interplay between bedrock topography and ice flow ${ }^{24}$. On Antarctica's floating ice shelves, $8,14,19,20,25$, water collects in surface depressions that move with ice flow. These ice shelf surface depressions are controlled by basal crevassing ${ }^{26}$, grounding zone flow-stripe development ${ }^{27}$, suture-zone depressions ${ }^{1}$ and basal channels produced by ocean melting ${ }^{28}$. Water will fill a depression if the ice surface or near surface is impermeable. Impermeable surfaces are often associated with high melt and low snow accumulation rates ${ }^{29}$. Once water collects in an ice shelf depression, the basin will deepen due to both enhanced lake-bottom ablation due to the lower albedo of the water compared to the surrounding ice/snow ${ }^{30,31}$, and the flexural response of the floating ice to the water load ${ }^{32,33}$. The largest supraglacial lake ( $\sim 80 \mathrm{~km}$ long) is on the Amery Ice Shelf (Figure 2e) ${ }^{13,14,34}$.

On both grounded and floating ice, surface fractures (crevasses) can accumulate water $^{26}$, serving as another storage site for meltwater and a mechanism by which water directly impacts ice dynamics. Water-filled fractures may propagate vertically when sufficient water is available, creating through-ice fractures on Antarctica's ice shelves $32,35,36$ and Greenland's floating tongues ${ }^{37}$. Fractures beneath Greenland lakes on the grounded ice drain meltwater to the ice-sheet bed by hydrofracture ${ }^{38,39}$. Currently, there is no direct evidence of hydrofracture beneath lakes on grounded Antarctic ice. 


\section{2b Englacial Storage of Meltwater}

Antarctic surface meltwater is stored englacially when surface lakes freeze-over and become buried by snowfall ${ }^{8,40}$. In Antarctica, buried lakes tend to form on ice shelves close to the grounding line ${ }^{8}$. Since at least 1947 on the Roi Baudouin Ice Shelf, meltwater produced in a blue ice area above and below the grounding line fills surface lakes. These lakes are buried as the ice moves towards the calving front ${ }^{14}$. Radar satellites, such as C-Band Sentinel-1 A and B, are capable of penetrating meters though dry snow, highlighting the promise of tracing buried lakes and other subsurface liquid water $^{41}$. When these grounding line lakes refreeze, they form massive ice layers ${ }^{29,42}$. Over successive melt seasons, frozen surface lakes, now stacked ice lenses, may accumulate in dense and thick ice horizons ${ }^{29}$. On the Larsen C Ice Shelf, a massive ice facies $>40 \mathrm{~m}$ thick extending $16 \mathrm{~km}$ horizontally was interpreted as a stack of frozen lakes $^{42}$. Temperature profiles through this refrozen ice are significant warmer due to the release of latent heat as the lakes froze, similar to the cryo-hydrologic warming described across Greenland $^{17}$.

In Greenland, perennial firn aquifers store water in environments similar to where buried supraglacial lakes form ${ }^{43}$. Water in these firn aquifers is stored in a porous matrix of ice crystals. No Antarctic firn aquifer has been sampled to date, but beneath ice massive facies on Larsen $\mathrm{C}$, a second $\sim 45 \mathrm{~m}$ thick ice unit has been interpreted as a percolation-type facies of water infiltrated firn ${ }^{42}$. In Antarctica, drainage systems often terminate where they deliver water into snow-covered areas ${ }^{1,8,12,14}$. Perennial firn aquifers could develop at these sites if accumulation rates are sufficiently high to insulate the downward percolating liquid water from low winter-time surface temperatures, or if the water is routed deep enough to be thermally-isolated from the surface. The perennial firn aquifers occur in Greenland ${ }^{17,44-48}$ in locations with both moderate to high melt rates (>650 mm w.e. $\left.\mathrm{yr}^{-1}\right)^{44}$ and high snow accumulation rates (e.g., $\sim 1-5 \mathrm{~m}$ w.e. $\left.\mathrm{yr}^{-1}\right)^{45}$. Similar high snow accumulation rates occur today on the western Antarctic Peninsula ${ }^{49}$, as well as on the upwind flanks of coastal domes and the ice sheet margins of West Antarctica, but surface melt rates are currently low in these regions.

\section{2c Surface Meltwater Transport}

Across broad sectors of Antarctica, meltwater transport over the surface of the ice-sheet and ice shelves occurs along relatively low surface slopes through networks of streams and rivers. In some cases, water moves 10 s to 100 s of kilometers ${ }^{14}$ and has persisted for decades. The Transantarctic Mountains support some of the continent's most high latitude $\left(\sim 85^{\circ} \mathrm{S}\right)$ and high elevation ( 1800 $\mathrm{m}$ a.s.l.) meltwater drainage systems (Figure 1). It is currently unclear how melting in these extreme locations supports these persistent drainage systems, but it is presumably related to the abundance of low-albedo bedrock and down-slope winds that emanate from the East Antarctic plateau. Streams and rivers may affect ice-sheet mass balance by moving water onto ice shelves where ponding water can contribute to ice-shelf collapse. Meltwater streams feed lakes in highalbedo snow on the Riiser-Larsen, Amery, Nivlisen and Roi Baudouin ice shelves ${ }^{8,14,50}$. Meltwater transport onto floating ice shelves will be especially important for influencing 
ice sheet mass balance if the water is delivered to ice shelves that are both susceptible to

fracture and buttress large upstream ice catchments.

Streams and rivers can also transport meltwater off ice shelves in the ocean via waterfalls $^{1}$ at the calving ice front, or through moulins, dolines and crevasses ${ }^{12,19}$. On the Nansen Ice Shelf ${ }^{1}$, a waterfall fed by a surface river has persisted since at least 1974 . This river and waterfall system drains a significant fraction of the meltwater formed on the ice shelf into the Ross Sea. Similar water export was observed on the Larsen B Ice Shelf prior to its collapse ${ }^{19}$ (Scambos pers. comm.). Simple routing calculations indicate that meltwater could be removed from other Antarctic ice shelves such as the Ross, Amery, Filchner Ronne and the Larsen $\mathrm{C}^{1}$. Transport of meltwater off floating ice shelves has the potential to buffer ice shelves from fracture and collapse associated with surface lakes.

\section{3) Drivers of Antarctic Surface Meltwater Distribution}

Currently, Antarctic surface meltwater distribution is driven by regional shifts in climate together with the influence of local scale process and microclimates. The predominance of melting on Antarctic Peninsula ice shelves today reflects the rapid regional atmospheric warming that began in the $1950 \mathrm{~s}^{51}$. The resulting melt intensification on ice shelves is thought to be directly responsible for multiple ice shelf collapses over recent decades ${ }^{52,53}$. These collapses, together with the associated loss of buttressing, have triggered Antarctic Peninsula outlet-glacier acceleration ${ }^{54}$. An ice core from James Ross Island on the northeast Antarctic Peninsula indicates that surface melting rapidly increased in the late 20th century relative to the past 1000 years ${ }^{55}$. Observed warming and melt intensification across the northeastern Antarctic Peninsula are associated with a strengthening of the circumpolar westerly winds marked by the positive phase shift in the Southern Annular Mode since the $1970 \mathrm{~s}^{56}$, which in turn is considered to be the result of coincident anthropogenically-induced depletion of stratospheric ozone ${ }^{57}$. Broader-scale climate dynamics also impact Antarctic surface melting, including oceanic-atmospheric variability in the tropical Pacific ${ }^{58,59}$. Striking examples of this linkage are anomalous, extensive melt events across the Ross Ice Shelf and the West Antarctic ice sheet that have been linked to an El Nino Southern Oscillation (ENSO) teleconnection pattern favoring warm, marine air intrusions into West Antarctica $^{5,9,60}$. Antarctic climate and surface melting are strongly coupled to broader climate system dynamics and anthropogenic forcing.

Local-scale processes also drive the distribution of Antarctic surface melt. Exposure of low-albedo blue ice and bedrock near ice shelf grounding zones can enhance melting through a positive melt-albedo feedback ${ }^{8,14}$. On the ice sheet, blue ice areas generally produce greater meltwater volumes than the adjacent snow-covered regions. As blue ice $^{22}$ only covers $1.6 \%$ of the surface of Antarctica ${ }^{61,62}$, the overall volume of meltwater produced by local-scale melt enhancement over blue ice areas is thought to be a small fraction of the Antarctic surface melt. Observations and modeling of meltwater production across ice-covered areas are particularly lacking in Antarctica.

Winds play an important role in surface meltwater production across Antarctica. Warming of descending katabatic winds that persistently drain from the Antarctic interior, and associated wind scouring and blue ice exposure are known to locally- 
enhance surface melting across ice shelf grounding zones in Dronning Maud Land, East Antarctica ${ }^{8}$. Analogous processes enhance melt on the Ross Ice Shelf, as well on the 186 innermost Amery Ice Shelf ${ }^{3,5}$. Foehn winds play a similar role in melt generation. Although more episodic and less directionally-constant than katabatics, warm, dry, and clear sky conditions associated with foehn wind events enhance melting across eastern Antarctic Peninsula ice shelves ${ }^{6,63,64}$ and the McMurdo Dry Valleys ${ }^{65,66}$. Local melt enhancement produced by foehn winds is linked to depletion of ice shelf firn pore space ${ }^{67}$ and meltwater ponding on innermost Larsen C Ice Shelf ${ }^{7,42,63}$. As firn air depletion results in impermeable ice surface this process is an important precursor for meltwater-induced hydrofracture ${ }^{6,68}$. Foehn winds likely contributed to the collapse of the Larsen B Ice Shelf ${ }^{69}$. A result of the interplay of Antarctic topography and prevailing winds, windenhanced melting will continue to be an important component of Antarctic surface meltwater production and hydrology in coming decades.

\section{4) Modes of Meltwater Impact on Ice Sheet Mass Balance}

Surface meltwater on ice sheets and the adjacent floating ice shelves has the potential to significantly impact ice-sheet mass-balance. We focus on three primary modes of meltwater influence on ice sheet mass balance: i) surface melt leading to direct surface runoff and thinning (Figure 3a,b); ii) changing the basal thermal and hydrological state by injection of surface meltwater into the subglacial environment (Figure 3c,d); and iii) meltwater-induced ice-shelf collapse (Figure 3e,f), producing an acceleration of mass loss from the upstream outlet glaciers. Other influences of surface meltwater include cryo-hydrologic warming and enhanced ocean melting ${ }^{70,71}$. Cryohydrologic warming in a lake, a crevasse or a firn aquifer can change the ice rheology both on grounded ice and ice shelves through the release of latent heat ${ }^{42}$.

The widespread and intense surface melt in Greenland today is a template for understanding surface hydrology in Antarctica in a warmer world. To date, the first mode, direct surface melt, is widespread in Greenland and on some Antarctic ice shelves ${ }^{14}$. The second mode, injection of surface water to the bed, is also widespread in Greenland $^{39,72,73}$ but has not yet been observed in Antarctica. The third mode, meltwater-induced ice-shelf collapse, has been implicated in the widespread collapses of northeast Antarctic Peninsula ice shelves, including the Larsen A and Prince Gustav in 1995, the Larsen B in 2002, and Wilkins in $2008^{11,35,36,74}$.

\section{4a) Mode 1: Surface Melt Leading To Direct Surface Runoff And Thinning}

In Antarctica, the first mode, direct ablation due to surface melt (Figure 3a,b), is primarily impacting ice shelves, whereas in Greenland, surface melt plays an important role in mass balance of the entire ice sheet. Prior to 2006, mass loss in Greenland was equally partitioned between losses from surface melt and runoff and loss due to ice dynamics $^{75}$. Beginning in 2006, the surface melt mass loss increased exceeding the mass loss attributed to ice dynamics ${ }^{75,76}$. Recently up to $\sim 84 \%$ of the annual mass loss from the Greenland Ice Sheet has been attributed to surface melt and runoff ${ }^{76}$. Surface melting and runoff have contributed to the lowering of the ice sheet margin at rates of $>1 \mathrm{~m} / \mathrm{yr}^{77}$. Close to the ice sheet margin, surface meltwater is exported directly off the ice in supraglacial streams. Inland, the surface water can refreeze, be stored near the surface 
44,78 or be transported to the ice sheet base ${ }^{38,39,79}$. As Antarctic melt rates increase in the future, mass loss due to surface runoff will also increase.

\section{$4 b$ Mode 2: Injection of Surface Meltwater Into The Subglacial Environment}

The second mode of impact, hydraulic connectivity between the ice-sheet surface and base (Figure 3c,d), has not been documented in Antarctica yet, but is widespread in Greenland. In Greenland, the surface and basal hydrological systems are linked by drainage of surface lakes into fractures ${ }^{79}$, and drainage of surface rivers into moulins ${ }^{80}$. Meltwater stored in the englacial hydrological system as subsurface lakes ${ }^{41,43}$ and firn aquifers $^{44}$ may also move surface water to the ice sheet base ${ }^{47}$. For example, transient storage of surface meltwater in a firn aquifer upslope of Helheim Glacier, east Greenland, flows downslope until it disappears at an extensional crevasse. Modeling suggests this water reaches the ice sheet bed via hydrofracture ${ }^{47}$. Surface water injection to the subglacial hydrological system may increase ice mass loss through enhanced basal sliding $^{2}$ and enhanced ocean melting at calving fronts. Sudden lake drainage events can produce both localized vertical and horizontal ice displacements ${ }^{38,39,81,82}$. Together, the seasonal evolution of surface meltwater, its transfer to the subglacial environment, and the efficiency of subglacial hydrological systems, modulate the response of ice dynamics to meltwater input ${ }^{83,84}$. In Greenland, research has focused on both the short-term (hours to weeks) ${ }^{38,39}$ and seasonal response of the ice sheet to meltwater injections ${ }^{85,86}$ as an analogue for understanding how the ice sheet will respond dynamically to increased surface melt. Presently there is no evidence for coupling between Antarctic surface and basal hydrological systems. As Antarctic climate warming results in the development on grounded ice of more extensive surface lakes, aquifers, and rivers, in some areas the surface and basal systems may connect. We suggest that a switch from an ice sheet base that is isolated from surface melt to one that receives seasonal injections of surface meltwater could trigger a fundamental shift in the dynamics and mass balance of Antarctica.

\section{4c Mode 3: Meltwater-Induced Ice-Shelf Collapse}

The third mode, meltwater-induced ice-shelf collapse (Figure 3e,f), is active today in Antarctica. Through-ice fractures on ice shelves may develop via two mechanisms: the downward propagation of water-filled fractures: ${ }^{68}$ Scambos, $2009 \# 1028$ referred to as hydrofracture, and fracturing resulting from the bending of an ice shelf as surface lakes fill and drain ${ }^{32,33,74}$.

Hydrofracture can occur on both floating and grounded ice. The process occurs when the hydrostatic pressure at the tip of a water-filled crevasse exceeds the ambient pressure sufficiently to induce stresses at the tip of the crevasse that exceed the fracture toughness. If water fills the fracture as it grows vertically, it may fracture the full ice thickness $\mathrm{s}^{35,36,47,68,87,88}$. Water can be supplied from a lake, stream, or firn aquifer. Whether hydrofracture triggers ice shelf collapse will depend on the fracture spacing. Closely spaced through-ice fractures are more likely to lead to an unstable ice shelf. When the fractured ice shelf fragments have aspect ratios of horizontal length to ice thickness less than a critical value $(\sim 0.6)^{89}$ iceberg capsize can drive ice shelf disintegration ${ }^{86,90}$. In contrast, widely spaced, fractures will not lead to iceberg capsize 
and instead may provide conduits to remove the surface meltwater buffering the ice shelf from collapse ${ }^{1,91}$.

Ponding of surface meltwater can also trigger ice shelf collapse through ice shelf flexing, weakening, and fracturing, as lakes fill and drain ${ }^{74,88}$. An ice shelf deflects downward when a surface lake fills, and hydrostatically rebounds upwards when a lake rapidly drains. This loading and unloading of surface lakes can produce flexurallyinduced ring and radial fractures around the lake ${ }^{74,92}$, as observed around drained lakes on the Shackleton Ice Shelf (Figure 1d) and the Langhovde Ice Shelf ${ }^{12}$, East Antarctica. A chain reaction of lake drainage events could occur if these loading-induced fractures intersect adjacent lakes. The adjacent lakes will drain into and deepen the new fracture. This chain reaction process may have triggered the drainage of over 2000 meltwater lakes $^{19}$ in the weeks prior to the collapse of the Larsen B Ice Shelf ${ }^{74}$. Meltwater-induced flexure and fracture may also have contributed to the 2008 break-up events of the Wilkins Ice Shelf ${ }^{11}$. Chain reaction lake drainages will only occur if lakes are close enough that fractures formed by one lake drainage event intersect an adjacent lake ${ }^{74}$. Stresses from further afield, including back-stress land-fast sea ice ${ }^{87}$ and larger-scale ice-flow, can mute the impact of loading and unloading by preventing fracture initiation. Some surface lakes have persisted on ice shelves, such as the George VI Ice Shelf, for decades without triggering collapse ${ }^{14}$. While every summer George VI Ice Shelf (Figure 1a) is covered with widespread, closely spaced lakes, its compressive flow regime ${ }^{93}$ limits the formation of fractures even with the persistent loading from abundant surface meltwater.

Most of our understanding of ice shelf collapse comes from the Antarctic Peninsula. It is likely that more Antarctic ice shelves will also be impacted by hydrofracture, as warming produces more melting in tandem with sustained windenhanced melting, resulting in reduced permeability of ice shelf firn and allowing formation of melt ponds in vulnerable areas.

\section{5) Meltwater Role in Future Antarctic Ice Sheet Mass Balance}

In the future, surface melting will play an increasingly important role in Antarctic Ice Sheet mass balance as the climate warms in response to greenhouse gas emissions ${ }^{94,95}$. The degree of influence will depend critically on melt rates, which increase nonlinearly with atmospheric temperatures, mainly as a result of the melt-albedo positive feedback ${ }^{94}$. This positive feedback heightens the sensitivity of warmer regions to future temperature increases, while also enabling melt to shift from a relatively insignificant process to a potentially dominant driver of ice shelf change over this century. Evidence for melttemperature nonlinearity and its impacts is provided by an ice core on the northeastern Antarctic Peninsula, documenting rapid melt intensification since the mid- $20^{\text {th }}$ century coincident with numerous ice shelf collapses ${ }^{55}$.

Simulations of future Antarctic surface melting vary widely, with the dominant source of uncertainty in projections resulting from the uncertainty in the future evolution of greenhouse gas emissions (i.e., scenario uncertainty). Additional uncertainty emerges from biases inherent to various climate models, as well as the configuration of modeling experiments and uncertainty with the parameterization of the meltwater transport, storage and influence on ice shelf fracture. Owing to the nonlinear sensitivity of melt to 
temperature change, even small biases in the simulation of present-day climate can case, models that do not reproduce melt conditions today project $200-500 \%$ more melt by $2100^{95}$ than a subset of climate models that are able to reproduce present-day melt rates ${ }^{94}$. Nevertheless, even under more conservative projections ${ }^{94}$, a near doubling of the Antarctic-wide volume of melt is simulated by 2050, irrespective of emissions scenario. Beyond mid-century, there is a close coupling between $\mathrm{CO} 2$ emissions and Antarctic melt. Under the high emissions RCP8.5 scenario, melt on nearly all Antarctic Peninsula ice shelves, and to a lesser degree on ice shelves further south in West Antarctica, approaches or surpasses levels associated with recent Antarctic Peninsula ice shelf collapses $^{94}$. Other projections with more intense surface melt ${ }^{95}$ suggest by that 2100 surface melt will trigger rapid and widespread Antarctic ice sheet mass losses through a progression of instability mechanisms including surface melt-induced ice shelf hydrofracture, marine ice cliff instability, and marine ice sheet instability ${ }^{89}$. Here we will focus on the more conservative of these two model-based studies, albeit under high emissions.

Figure 4 compares melt rates projected for the end of the century in Antarctica under emissions scenario RCP8.5, to present-day melt rates in Greenland. This provides a framework for understanding the future impact of melt in Antarctica. The region that will experience the greatest increase in surface melt will be the Antarctic Peninsula. Melt rates as high as in Greenland's lower ablation zone, where surface meltwater is connected to the bed, are projected for this region by 2100. Melt intensity is strongly dependent on elevation and latitude. If not already at risk of collapse due intensified surface melting ${ }^{94}$, Antarctic Peninsula ice shelves will likely deplete their firn air content under high emissions by the end of the century ${ }^{6}$. Lack of pore space within the firn layer Antarctic Peninsula ice shelves will heighten their sensitivity to further melt increases by promoting meltwater pooling or runoff as opposed to percolation and refreezing ${ }^{45}$. A simplistic interpretation of this comparison suggests that bare ice zones, melt lakes, and moulins will replace percolation zones that proliferate across much of floating and grounded ice of the Antarctic Peninsula today. This could trigger several meltwater impacts that are active in Greenland today but currently negligible in Antarctica, including meltwater runoff and injection of meltwater to the bed. Given historical meltrate and temperature-based thresholds for ice-shelf viability ${ }^{94}$, Larsen C Ice Shelf and others on the Antarctic Peninsula can be expected to collapse under this emissions scenario this century ${ }^{35,53}$. With high melt intensification projected and increased snowfall already observed $^{96}$, firn aquifers and subsurface lakes may develop along the Antarctic Peninsula.

The impact of surface hydrology on ice sheet mass balance in other parts of Antarctica will grow as the extent and intensity of surface melt increases. The ponding of meltwater on ice shelves, where active drainage by stream and rivers could contribute to their collapse. Whether water is exported by ice shelf rivers will depend on surface slope, surface conditions, and the ice shelf stress state. If predictions of increased melting are accurate, by 2100 the Antarctic Peninsula ice shelves will probably have collapsed and all remaining ice shelves including the large Ross, Filchner-Ronne and Amery will undergo firn densification due to the increased surface melt. Atmospherically-driven 
surface lowering due to firn compaction would be occurring in tandem with ocean-driven basal thinning of ice shelves that is already acting upon much of peripheral Antarctica ${ }^{97,98}$. Meltwater may collect at the grounding lines of the large ice shelves similar to the ponding and refreezing at the grounding line of the Larsen C Ice Shelf today. The elevated surface melt on the Abbott, Getz and Shackleton ice shelves will have led to the collapse of these ice shelves unless active surface drainage can mitigate the effect of surface loading by exporting water to the ocean.

On the grounded portion of East and West Antarctica, surface lowering due to runoff and connectivity to the bed (modes 1 and 2, Figure 3) could become significant by 2100 in select regions. Regions where 2100 melt rates similar to those observed in Greenland today develop on grounded Antarctic ice include the Pine Island catchment and portions of Wilkes Land, East Antarctica. We expect that areas of englacial water storage, including firn aquifers and buried lakes, will expand as accumulation and precipitation increase simultaneously this century ${ }^{99}$.

Increased snow accumulation, a result of a warming atmosphere, is likely to moderate the impact of melt. Recent coupled climate modeling indicates that owing to enhanced moisture-holding capacity of the atmosphere and increased open-ocean evaporation, Antarctic surface mass balance may increase by $70 \mathrm{Gt} / \mathrm{yr}$ per degree warming even as surface melt and runoff increase ${ }^{99}$. Evidence for ongoing warmingenhanced snowfall is preserved in ice cores. Increased snowfall could also inhibit the melt-albedo feedback, an important for melt initiation and seasonal melt evolution on East Antarctic ice shelves ${ }^{7}$. Enhanced snowfall may also support growth of ice shelf/sheet firn layer and thus enable enhanced meltwater infiltration and refreeze as opposed to ponding ${ }^{45}$ or promote future growth in meltwater storage in aquifers ${ }^{45,18}$. If the firn layer thickens more meltwater will infiltrate and refreeze or be stored in firn aquifers ${ }^{18}$ rather than ponding on the ice surface ${ }^{45}$. While increased accumulation may buffer the impact of increased surface melt on runoff and ice shelf collapse, if increased accumulation leads to the formation of extensive firn aquifers in crevassed regions, connectivity between the surface and basal hydrologic systems may develop. Similarly, an increase in ice flux could result from meltwater injected into ice shear margins or into regions of Antarctica with cold frozen beds.

To move beyond simple projections of modern Greenland hydrology to a warmer Antarctica requires an improved understanding of surface hydrology on ice shelves and ice sheets. For improving our understanding of ice-shelf collapse, knowledge gaps are profound in our understanding of the role of firn densification, the roles of hydrofracture and meltwater-loading induced-flexure on ice-shelf fracture and calving, how effective surface rivers are in buffering ice shelves from collapse. Similarly, for grounded ice, we do not have a clear understanding of what happens when surface melt first reaches the base of an ice sheet. Because of melt-temperature nonlinearity and the varied local and global-scale processes impacting melt, it is essential for climate and ice sheet models to realistically simulate present-day Antarctic climate. 
Accurate estimates of surface meltwater production today are hampered by lack of continuity in satellite datasets, and the sparse spatial and temporal in situ observations necessary to constrain the surface energy balance. New satellite campaigns (e.g., Landsat 8 and the Sentinel constellation), and dedicated field campaigns in melt-prone areas are beginning to address this observation void. Collection of new constraints on ice structure, the evolution and drivers of melt through time, and the vulnerability of ice shelves to hydrofracture should include ice cores and geophysical mapping. Sustained, and robust observations are needed of Antarctic surface melt and hydrological processes, in particular to constrain their varied drivers and impacts on ice properties and stability, in order to develop and refine parameterizations of these processes in continental-scale ice sheet models. These are critical knowledge gaps that limit our understanding of future Antarctic mass change. Addressing these uncertainties will require a sustained, coordinated, international, and interdisciplinary effort.

The impact of increased surface melting on the mass balance of the Antarctic Ice Sheet will depend on the fate of the meltwater both as melt on vulnerable buttressing ice shelves increases and on the grounded ice begins to resemble the melt storage, transport, and export active today in Greenland. Whether future surface melt and hydrology resembles that experienced by early Antarctic explorers, or that like occurs in Greenland today, is tied in large part to the future emissions of greenhouse gases. In the near future, surface melt processes will have the greatest impact on global sea level through susceptible ice shelves buttressing large catchments. When and where each mode of meltwater impact - direct thinning, injection of meltwater to the bed and hydrofracture are activated in a wetter, warmer Antarctica will in part control to how much Antarctica contributes to global sea-level rise.

Author Contribution Statement - REB conceived the idea and all authors contributed equally.

REB is the author to whom correspondence and requests for materials should be addressed.

Acknowledgements - AFB acknowledges support from a Leverhulme/Newton Trust Early Career Fellowship (ECF-2014-412). We thank Xavier Fettweis for producing and making Greenland MAR model output available and Marco Tedesco for discussion on their usage. The authors thank Olga Sergienko for useful discussions. The authors gratefully acknowledge the participants in the February 2018 NSF-funded workshop on Antarctic Surface Hydrology and Future Ice Shelf Stability (grant number 1743326) for their lively, thoughtful discussion. LDT acknowledges support from NSF Antarctic Glaciology Program award 1643733.

\section{Competing Interests}

458 


\section{Figure Captions}

Figure 1 Examples Of Major Components Of Surface Hydrological Systems Located A On Current-Day Antarctic Surface Melt Map a) Meltwater lakes and dolines (arrows), b) Foehn wind-enhanced meltwater ponding. c) Buried lake (credit: Stef Lhermitte). d) Moulin draining surface stream (credit: Jan Lenaerts). e) Elongate supraglacial lake. f) Fractures around a drained lake (1947 USGS aerial photograph). Scale unknown. g) Persistent waterfall draining water (credit: Won Sang Lee). h) Supraglacial streams transporting water across the Darwin Glacier grounding line onto the Ross Ice Shelf. i) High elevation (1830 m) meltwater stream (credit: Mike Kaplan). j) Meltwater stream crossing the grounding line, (credit: John Stone). k) Map of 2000-2009 Antarctica surface melt from QuikSCAT satellite observation ${ }^{7}$ showing image locations.

Figure 2 Antarctic Surface Hydrology Components Illustration of the major components of the modern Antarctic hydrologic system. Possible future surface to bed connection is included illustrated as a lake-bottom fracture draining meltwater to ice sheet base, based on Greenland analogues. Dolines are locally uplifted, empty depressions, interpreted as evidence of surface lakes having drained through ice shelves through-ice fractures.

Figure 3 Schematic Illustration of Three Primary Modes of Surface Melt Impact on Ice Sheet Mass Balance a) Mode 1 - Direct surface ablation enhanced over lakebottoms owing to albedo feedback ${ }^{30}$ that results incoming shortwave radiation reflecting less (small yellow arrow) from lakes than adjacent snow or bare ice surfaces (larger arrow). b) Mode 2 - Connectivity between ice surface hydrology and ice sheet base impacting ice dynamics by modifying basal thermal and hydrologic conditions. Connections may occur through surface lakes draining into fractures, via rivers draining into moulins, and via firn aquifers draining into fractures. Changing basal conditions can alter ice dynamics. c) Mode 3: Meltwater-induced ice-shelf collapse due to presence of surface lakes. Surface lakes: i) propagate pre-existing fractures downward by hydrofracture (light blue lake and fracture) ${ }^{68,88}$. and ii) load (or unload) the ice shelf, creating new fractures (dark blue lake and fractures) that drain adjacent lakes ${ }^{74}$; When an ice shelf collapses, mass loss will increase as decreased the buttressing force will trigger the incoming outlet glaciers accelerate.

Figure 4. Surface Meltwater Production In Greenland Today And Antarctica At EndOf-Century a) Mean annual surface melting in Greenland as simulated over 2000-2009 by MARv3.5.2 forced by ERA-Interim ${ }^{100}$, and b)projected over 2091-2100 in Antarctica under the high-emissions RCP8.5 scenario using an ensemble of CMIP5-based models ${ }^{94}$. Note that the color scale in this figure is different to the color scale used in Figure 1. Surface elevation contour interval is $500 \mathrm{~m}$. 


\section{References to Highlight}

Banwell, A. F., MacAyeal, D. R. \& Sergienko, O. V. Breakup of the Larsen B Ice Shelf triggered by chain reaction drainage of supraglacial lakes. Geophysical Research Letters 40, 5872-5876 (2013).

Shows that a surface lake drainage event on an ice shelf may produce fractures that intersect other lakes, initiating the self-stimulating lake drainage mechanism that the authors propose may have contributed to the widespread break-up of the Larsen B Ice Shelf in 2002.

Bell, R. E. et al. Antarctic ice shelf potentially stabilized by export of meltwater in surface river. Nature 544, 344 (2017).

Presents evidence of persistent removal of surface meltwater from an ice shelf by a surface river and the potential to develop surface drainage on Antarctica's large ice shelves.

Bevan, S. L. et al. Centuries of intense surface melt on Larsen C Ice Shelf. The Cryosphere 11, 2743 (2017).

Using observations from five $90 \mathrm{~m}$ deep boreholes and results from a flow-line model and a firn densification model, this study shows that stacked layers of refrozen pond ice correspond to two climatic warm periods within the last $\mathbf{3 0 0}$ years on the Antarctic Peninsula

DeConto, R. M. \& Pollard, D. Contribution of Antarctica to past and future sea-level rise. Nature 531, 591-597 (2016).

Includes new parameterizations for ice shelf hydrofracture and ice cliff failure in an ice sheet-climate model, suggesting atmospheric warming may drive Antarctic mass losses, both in previous warm periods, as well as in the $21^{\text {st }}$ century and beyond.

Kingslake, J., Ely, J. C., Das, I. \& Bell, R. E. Widespread movement of meltwater onto and across Antarctic ice shelves. Nature 544, 349-352 (2017).

Presents satellite evidence for widespread meltwater ponds, streams and rivers on the flanks of Antarctic Ice Sheets and surrounding ice shelves, suggesting that active surface hydrology is more common today than previously thought.

Langley, E. S., Leeson, A. A., Stokes, C. R. \& Jamieson, S. S. R. Seasonal evolution of supraglacial lakes on an East Antarctic outlet glacier. Geophysical Research Letters 43, 8563-8571 (2016).

One of the first detailed multi-year analysis of surpraglacial pond formation and drainage in East Antarctica, suggesting three ways in which lakes evolve: refreeze, drainage englacially or drain supraglacially.

Lenaerts, J. T. M. et al. Meltwater produced by wind-albedo interaction stored in an East Antarctic ice shelf. Nature Climate Change 7, 58 (2017). 
551 Shows that surface melting is enhanced near the grounding zone of at least one East 552 Antarctic ice shelf due to positive wind-albedo-melt feedbacks, suggesting potential 553 for ice shelf hydrofracture beyond the Antarctic Peninsula.

554

Trusel, L. D. et al. Divergent trajectories of Antarctic surface melt under two twentyfirst-century climate scenarios. Nature Geoscience (2015).

558

559 Shows that surface melting in Antarctica grows exponentially in response to a warming atmosphere, and that by 2100 under high emissions, multiple ice shelves exceed levels of melt associated with previous ice shelf collapses. warming and break-up of ice shelves in the Antarctic Peninsula. Journal of Glaciology 46, 516-530 (2000).

564 Outlines concept that loading of Antarctic Pennisula ice shelves by surface meltwater contributed to the ice sehlf collapse 


\section{References: Antarctic Surface Hydrology and Impacts on Ice Sheet Mass Balance August 2018}

1 Bell, R. E. et al. Antarctic ice shelf potentially stabilized by export of meltwater in surface river. Nature 544, 344-348 (2017).

2 Zwally, H. J. \& Fiegles, S. Extent and duration of Antarctic surface melting. Journal of Glaciology 40, 463-475 (1994).

3 Liu, H., Wang, L. \& Jezek, K. C. Spatiotemporal variations of snowmelt in Antarctica derived from satellite scanning multichannel microwave radiometer and Special Sensor Microwave Imager data (1978-2004). Journal of Geophysical Research: Earth Surface 111 (2006).

4 Tedesco, M., Abdalati, W. \& Zwally, H. J. Persistent surface snowmelt over Antarctica (1987-2006) from 19.35 GHz brightness temperatures. Geophysical Research Letters 34 (2007).

5 Trusel, L. D., Frey, K. E. \& Das, S. B. Antarctic surface melting dynamics: Enhanced perspectives from radar scatterometer data. Journal of Geophysical Research: Earth Surface 117 (2012).

6 Munneke, P. K., Ligtenberg, S. R. M., Van den Broeke, M. R. \& Vaughan, D. G. Firn air depletion as a precursor of Antarctic ice-shelf collapse. Journal of Glaciology 60, 205-214 (2014). Trusel, L. D., Frey, K. E., Das, S. B., Munneke, P. K. \& Broeke, M. R. Satellitebased estimates of Antarctic surface meltwater fluxes. Geophysical Research Letters 40, 6148-6153 (2013).

8 Lenaerts, J. T. M. et al. Meltwater produced by wind-albedo interaction stored in an East Antarctic ice shelf. Nature Climate Change 7, 58 (2017).

9 Nicolas, J. P. et al. January 2016 extensive summer melt in West Antarctica favoured by strong El Niño. Nature Communications 8 (2017).

10 Nghiem, S. et al. The extreme melt across the Greenland ice sheet in 2012. Geophysical Research Letters 39 (2012).

11 Glasser, N. F. et al. Surface structure and stability of the Larsen C ice shelf, Antarctic Peninsula. Journal of Glaciology 55, 400-410 (2009).

12 Langley, E. S., Leeson, A. A., Stokes, C. R. \& Jamieson, S. S. R. Seasonal evolution of supraglacial lakes on an East Antarctic outlet glacier. Geophysical Research Letters 43, 8563-8571 (2016).

13 Phillips, H. A. Surface meltstreams on the Amery Ice Shelf, East Antarctica. Annals of Glaciology 27, 177-181 (1998).

14 Kingslake, J., Ely, J. C., Das, I. \& Bell, R. E. Widespread movement of meltwater onto and across Antarctic ice shelves. Nature 544, 349-352 (2017).

15 Bindschadler, R., Scambos, T. A., Rott, H., Skvarca, P. \& Vornberger, P. Ice dolines on Larsen Ice Shelf, Antarctica. Annals of Glaciology 34, 283-290 (2002).

614 Humphrey, N. F., Harper, J. T. \& Pfeffer, W. T. Thermal tracking of meltwater retention in Greenland's accumulation area. Journal of Geophysical Research: Earth Surface 117 (2012). 
61517 Polashenski, C. et al. Observations of pronounced Greenland ice sheet firn 616 warming and implications for runoff production. Geophysical Research Letters 617 41, 4238-4246 (2014).

61818 Munneke, P. K. et al. Intense winter surface melt on an Antarctic ice shelf. $619 \quad$ Geophysical Research Letters (2018).

62019 Glasser, N. F. \& Scambos, T. A. A structural glaciological analysis of the 2002 Larsen B ice-shelf collapse. Journal of Glaciology 54, 3-16 (2008).

623

624

625

20 Banwell, A. F. et al. Supraglacial lakes on the Larsen B ice shelf, Antarctica, and at Paakitsoq, West Greenland: a comparative study. Annals of Glaciology 55, 1-8 (2014).

21 Liston, G. E., Winther, J.-G., Bruland, O., Elvehøy, H. \& Sand, K. Below-surface ice melt on the coastal Antarctic ice sheet. Journal of Glaciology 45, 273-285 (1999).

22 Liston, G. E. \& Winther, J.-G. Antarctic surface and subsurface snow and ice melt fluxes. Journal of Climate 18, 1469-1481 (2005).

631

632

633

634

635

23 Winther, J.-G., Elvehøy, H., Bøggild, C. E., Sand, K. \& Liston, G. Melting, runoff and the formation of frozen lakes in a mixed snow and blue-ice field in Dronning Maud Land, Antarctica. Journal of Glaciology 42, 271-278 (1996).

24 Echelmeyer, K., Clarke, T. S. \& Harrison, W. D. Surficial glaciology of Jakobshavns Isbræ, West Greenland: Part I. Surface morphology. Journal of Glaciology 37, 368-382 (1991).

25 Miles, B. W. J., Stokes, C. R., Vieli, A. \& Cox, N. J. Rapid, climate-driven changes in outlet glaciers on the Pacific coast of East Antarctica. Nature 500, 563 (2013).

26 McGrath, D. et al. Basal crevasses on the Larsen C Ice Shelf, Antarctica: Implications for meltwater ponding and hydrofracture. Geophysical Research Letters 39 (2012).

643

27 Glasser, N. F. \& Gudmundsson, G. H. Longitudinal surface structures (flowstripes) on Antarctic glaciers. The Cryosphere 6, 383-391 (2012). shelf fracture. Science Advances 4 (2018). Bevan, S. L. et al. Centuries of intense surface melt on Larsen C Ice Shelf. The Cryosphere 11, 2743 (2017).

Tedesco, M. et al. Measurement and modeling of ablation of the bottom of supraglacial lakes in western Greenland. Geophysical Research Letters 39 (2012).

31 Lüthje, M., Pedersen, L. T., Reeh, N. \& Greuell, W. Modelling the evolution of supraglacial lakes on the West Greenland ice-sheet margin. Journal of Glaciology 52, 608-618 (2006). (2009). 
66135 Scambos, T. et al. Ice shelf disintegration by plate bending and hydro-fracture: 662 Satellite observations and model results of the 2008 Wilkins ice shelf break-ups. $663 \quad$ Earth and Planetary Science Letters 280, 51-60 (2009).

$66436 \quad$ Scambos, T. A., Hulbe, C., Fahnestock, M. \& Bohlander, J. The link between

38 Das, S. B. et al. Fracture Propagation to the Base of the Greenland Ice Sheet

During Supraglacial Lake Drainage. Science 320, 778-781 (2008). climate warming and break-up of ice shelves in the Antarctic Peninsula. Journal of Glaciology 46, 516-530 (2000).

37 Macdonald, G. J., Banwell, A. F. \& MacAyeal, D. R. Seasonal evolution of supraglacial lakes on a floating ice tongue, Petermann Glacier, Greenland. Annals of Glaciology 59, 56-65 (2018).

Tedesco, M. et al. Ice dynamic response to two modes of surface lake drainage on the Greenland ice sheet. Environmental Research Letters 8 (2013).

Paige, R. A. Sub-surface melt pools in the McMurdo Ice Shelf, Antarctica. Journal of Glaciology 7, 511-516 (1968).

41 Miles, K. E., Willis, I. C., Benedek, C. L., Williamson, A. G. \& Tedesco, M. Toward monitoring surface and subsurface lakes on the Greenland ice sheet using Sentinel-1 SAR and Landsat-8 OLI imagery. Frontiers in Earth Science 5, 58 (2017).

42 Hubbard, B. et al. Massive subsurface ice formed by refreezing of ice-shelf melt ponds. Nature Communications 7, 11897 (2016).

43 Koenig, L. S. et al. Wintertime storage of water in buried supraglacial lakes across the Greenland Ice Sheet. The Cryosphere 9, 1333-1342 (2015).

44 Forster, R. R. et al. Extensive liquid meltwater storage in firn within the Greenland ice sheet. Nature Geoscience 7, 95-98 (2014).

45 Munneke, P. K., M Ligtenberg, S. R., Broeke, M. R., Angelen, J. H. \& Forster, R. R. Explaining the presence of perennial liquid water bodies in the firn of the Greenland Ice Sheet. Geophysical Research Letters 41, 476-483 (2014).

46 Miège, C. et al. Spatial extent and temporal variability of Greenland firn aquifers detected by ground and airborne radars. Journal of Geophysical Research: Earth Surface 121, 2381-2398 (2016).

47 Poinar, K. et al. Drainage of Southeast Greenland firn aquifer water through crevasses to the bed. Frontiers in Earth Science 5, 5 (2017).

48 Miller, O. L. et al. Hydraulic conductivity of a firn aquifer in southeast Greenland. Frontiers in Earth Science 5, 38 (2017).

49 Noël, B. et al. Modelling the climate and surface mass balance of polar ice sheets using RACMO2-Part 1: Greenland (1958-2016). The Cryosphere 12, 811 (2018). Kingslake, J. \& Sole, A. Modelling channelized surface drainage of supraglacial lakes. Journal of Glaciology 61, 185-199 (2015).

51 Turner, J. Significant warming of the Antarctic winter troposphere. Science 311, 1914-1917 (2006).

706

Scambos, T., Hulbe, C. \& Fahnestock, M. Climate-induced ice shelf disintegration in the Antarctic peninsula. Antarctic Peninsula Climate Variability: Historical and Paleoenvironmental Perspectives, 79-92 (2003).

53 Vaughan, D. G. \& Doake, C. S. M. Recent atmospheric warming and retreat of ice shelves on the Antarctic Peninsula. Nature 379, 328 (1996). 
54 Pritchard, H. D. \& Vaughan, D. G. Widespread acceleration of tidewater glaciers on the Antarctic Peninsula. Journal of Geophysical Research: Earth Surface 112 (2007).

Abram, N. J. et al. Acceleration of snow melt in an Antarctic Peninsula ice core during the twentieth century. Nature Geoscience 6, 404 (2013). Marshall, G. J. Trends in the Southern Annular Mode from observations and reanalyses. Journal of Climate 16, 4134-4143 (2003).

Thompson, D. W. et al. Signatures of the Antarctic ozone hole in Southern Hemisphere surface climate change. Nature Geoscience 4, 741 (2011).

58 Tedesco, M. \& Monaghan, A. J. An updated Antarctic melt record through 2009 and its linkages to high-latitude and tropical climate variability. Geophysical Research Letters 36 (2009).

9 Deb, P. et al. Summer drivers of atmospheric variability affecting ice shelf thinning in the Amundsen Sea Embayment, West Antarctica. Geophysical Research Letters 45, 4124-4133 (2018).

60 Nicolas, J. P. \& Bromwich, D. H. Climate of West Antarctica and influence of marine air intrusions. Journal of Climate 24, 49-67 (2011).

61 Winther, J.-G., Jespersen, M. N. \& Liston, G. E. Blue-ice areas in Antarctica derived from NOAA AVHRR satellite data. Journal of Glaciology 47, 325-334 (2001).

62 Hui, F. et al. Mapping blue-ice areas in Antarctica using ETM+ and MODIS data. Annals of Glaciology 55, 129-137 (2014).

63 Luckman, A. et al. Surface melt and ponding on Larsen C Ice Shelf and the impact of foehn winds. Antarctic Science 26, 625-635 (2014).

64 Turton, J. V., Kirchgaessner, A., Ross, A. N. \& King, J. C. Does high-resolution modelling improve the spatial analysis of föhn flow over the Larsen C Ice Shelf? Weather 72, 192-196 (2017).

65 Barrett, J. E. et al. Persistent effects of a discrete warming event on a polar desert ecosystem. Global Change Biology 14, 2249-2261 (2008).

66 Speirs, J. C., Steinhoff, D. F., McGowan, H. A., Bromwich, D. H. \& Monaghan, A. J. Foehn winds in the McMurdo Dry Valleys, Antarctica: The origin of extreme warming events. Journal of Climate 23, 3577-3598 (2010).

67 Stern, A. A., Dinniman, M. S., Zagorodnov, V., Tyler, S. W. \& Holland, D. M. Intrusion of warm surface water beneath the McMurdo ice shelf, Antarctica. Journal of Geophysical Research: Oceans 118, 7036-7048 (2013).

68 van der Veen, C. J. Fracture propagation as means of rapidly transferring surface meltwater to the base of glaciers. Geophysical Research Letters 34 (2007).

69 Cape, M. R. et al. Foehn winds link climate-driven warming to ice shelf evolution in Antarctica. Journal of Geophysical Research: Atmospheres 120 (2015).

70 Straneo, F. et al. Impact of fjord dynamics and glacial runoff on the circulation near Helheim Glacier. Nature Geoscience 4, 322 (2011).

71 Fried, M. J. et al. Distributed subglacial discharge drives significant submarine melt at a Greenland tidewater glacier. Geophysical Research Letters 42, 93289336 (2015).

72 Bartholomew, I. et al. Supraglacial forcing of subglacial drainage in the ablation zone of the Greenland ice sheet. Geophysical Research Letters 38 (2011). 
75373 Hoffman, M., Catania, G., Neumann, T., Andrews, L. \& Rumrill, J. Links between acceleration, melting, and supraglacial lake drainage of the western Greenland Ice Sheet. Journal of Geophysical Research: Earth Surface 116 (2011). Shelf triggered by chain reaction drainage of supraglacial lakes. Geophysical Research Letters 40, 5872-5876 (2013).

75 van den Broeke, M. et al. Partitioning recent Greenland mass loss. science 326, 984-986 (2009).

76 Enderlin, E. M. et al. An improved mass budget for the Greenland ice sheet. Geophysical Research Letters 41, 866-872 (2014).

77 Csatho, B. M. et al. Laser altimetry reveals complex pattern of Greenland Ice Sheet dynamics. Proceedings of the National Academy of Sciences 111, 1847818483 (2014).

Cooper, M. G. et al. Meltwater storage in low-density near-surface bare ice in the Greenland ice sheet ablation zone. The Cryosphere 12, 955 (2018).

Willis, M. J., Herried, B. G., Bevis, M. G. \& Bell, R. E. Recharge of a subglacial lake by surface meltwater in northeast Greenland. Nature 518, 223-227 (2015).

Smith, L. C. et al. Efficient meltwater drainage through supraglacial streams and rivers on the southwest Greenland ice sheet. Proceedings of the National Academy of Sciences 112, 1001-1006 (2015).

81 Stevens, L. A. et al. Greenland supraglacial lake drainages triggered by hydrologically induced basal slip. Nature 522, 73 (2015).

82 Joughin, I. Seasonal speedup along the western flank of the Greenland Ice Sheet. Science 320, 781-783 (2008).

83 Sundal, A. V. et al. Melt-induced speed-up of Greenland ice sheet offset by efficient subglacial drainage. Nature 469, 521 (2011).

84 Tedstone, A. J. et al. Greenland ice sheet motion insensitive to exceptional meltwater forcing. Proceedings of the National Academy of Sciences 110, 1971919724 (2013).

85 Hoffman, M. J. et al. Widespread Moulin Formation During Supraglacial Lake Drainages in Greenland. Geophysical Research Letters 45, 778-788 (2018).

86 Banwell, A., Hewitt, I., Willis, I. \& Arnold, N. Moulin density controls drainage development beneath the Greenland ice sheet. Journal of Geophysical Research: Earth Surface 121, 2248-2269 (2016).

87 Van der Veen, C. J. Fracture mechanics approach to penetration of surface crevasses on glaciers. Cold Regions Science and Technology 27, 31-47 (1998).

88 MacAyeal, D. R. \& Sergienko, O. V. The flexural dynamics of melting ice shelves. Annals of Glaciology 54, 1-10 (2013).

89 Burton, J. C. et al. Laboratory investigations of iceberg capsize dynamics, energy dissipation and tsunamigenesis. Journal of Geophysical Research: Earth Surface 117 (2012).

90 MacAyeal, D. R., Scambos, T. A., Hulbe, C. L. \& Fahnestock, M. A. Catastrophic ice-shelf break-up by an ice-shelf-fragment-capsize mechanism. Journal of Glaciology 49, 22-36 (2003). 
79891 Banwell, A. Glaciology: Ice-shelf stability questioned. Nature 544, 306-307 799 (2017).

80092 Beltaos, S. Collapse of floating ice covers under vertical loads: test data vs.

801 theory. Cold Regions Science and Technology 34, 191-207 (2002).

93 Hambrey, M. J. et al. Structure and sedimentology of George VI Ice Shelf, Antarctic Peninsula: implications for ice-sheet dynamics and landform development. Journal of the Geological Society 172, 599-613 (2015).

806

94 Trusel, L. D. et al. Divergent trajectories of Antarctic surface melt under two twenty-first-century climate scenarios. Nature Geoscience (2015). DeConto, R. M. \& Pollard, D. Contribution of Antarctica to past and future sealevel rise. Nature 531, 591-597 (2016).

Thomas, E. R., Marshall, G. J. \& McConnell, J. R. A doubling in snow accumulation in the western Antarctic Peninsula since 1850. Geophysical Research Letters 35 (2008).

Pritchard, H. D. et al. Antarctic ice-sheet loss driven by basal melting of ice shelves. Nature 484, 502 (2012).

815 Broeke, M. R. Present-day and future Antarctic ice sheet climate and surface mass balance in the Community Earth System Model. Climate Dynamics 47, 13671381 (2016).

100 Fettweis, X. et al. Reconstructions of the 1900-2015 Greenland ice sheet surface mass balance using the regional climate MAR model. The Cryosphere 11, 1015 (2017). 
a

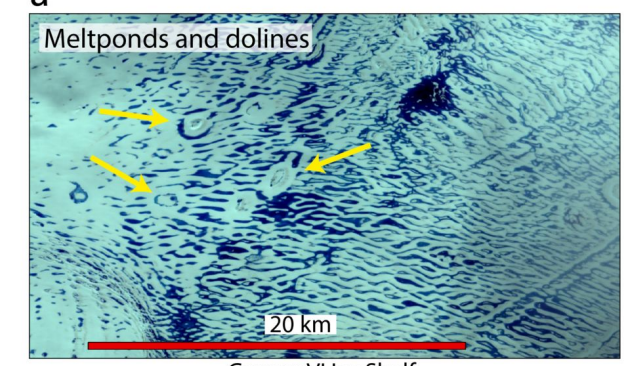

George VI Ice Shelf
10 January 2003

j

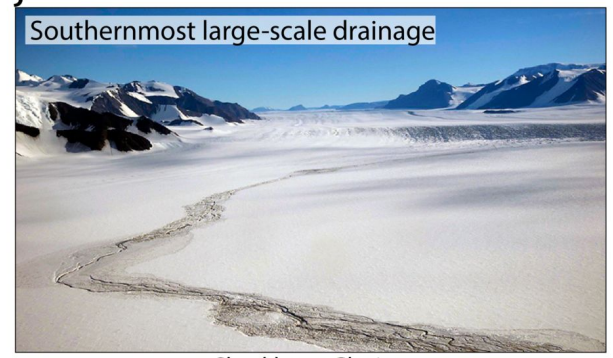

Shackleton Glacier

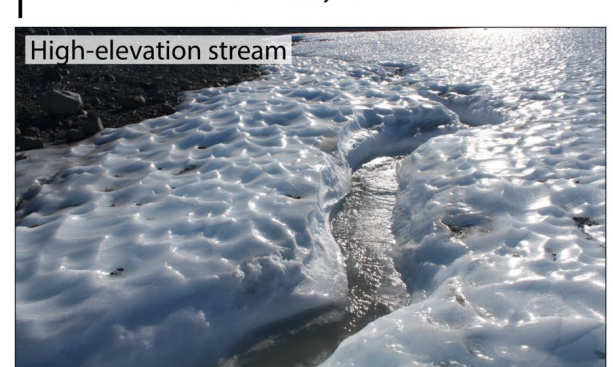

Law Glacier ( 1,830 m a.s.I.)

$\mathrm{h}$

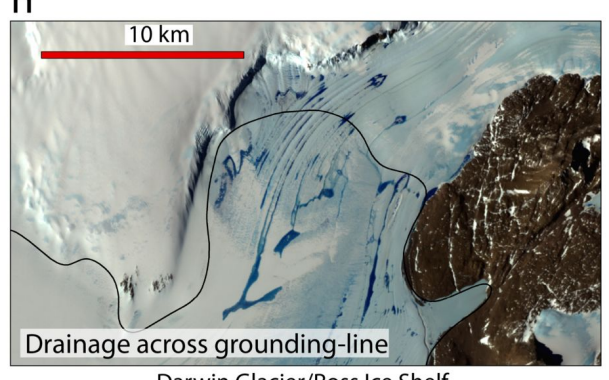

Darwin Glacier/Ross Ice Shelf 31 December 2001 b
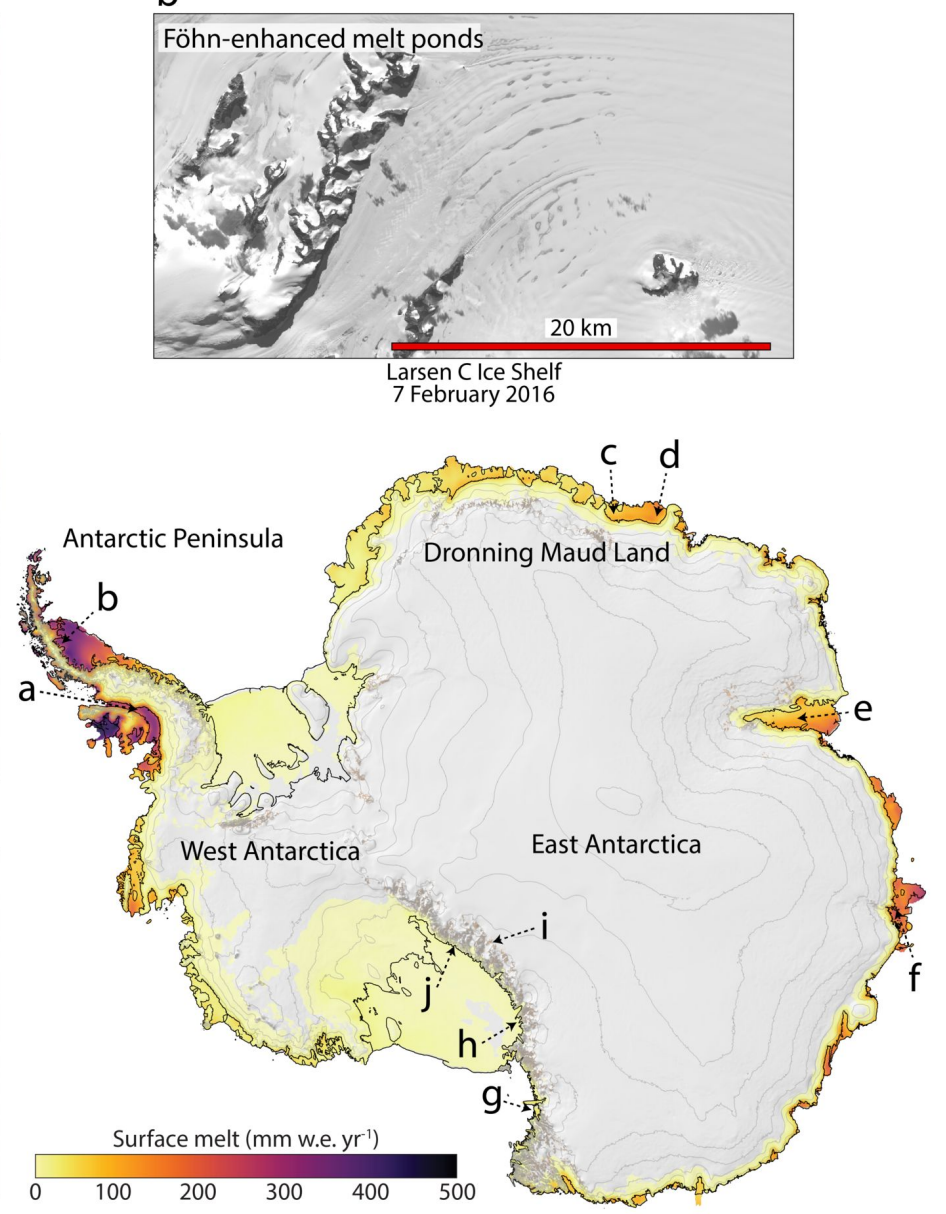

$\mathrm{g}$

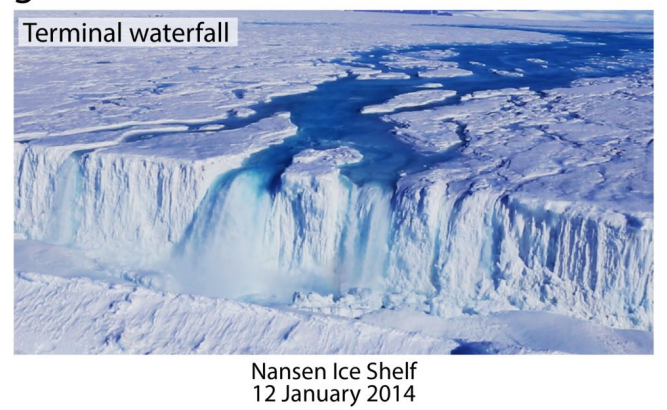

C

\section{Subsurface lake}

\section{d} Western Roi Baudouin Ice Shelf
January/February 2016

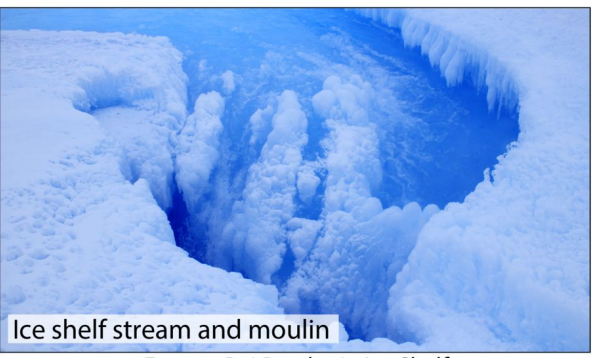

Ice shelf stream and moulin
Eastern Roi Baudouin Ice Shelf

$$
\text { e January/February } 2016
$$

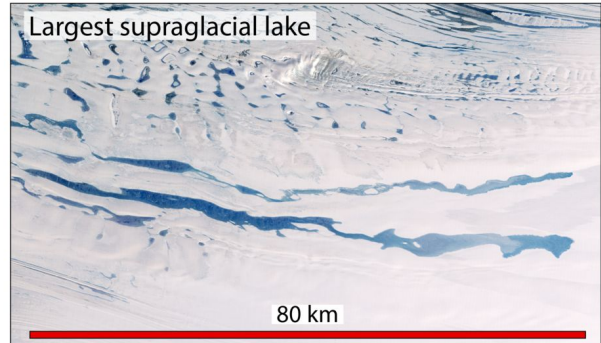

$\mathrm{f}$

Amery lce Shelf

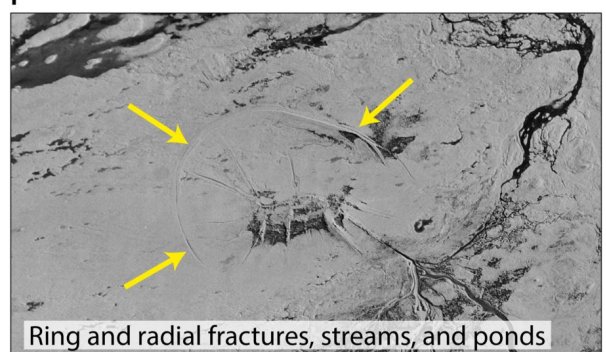

Ring and radial fractures, streams, and ponds

Shackleton Ice Shelf
10 February 1947 


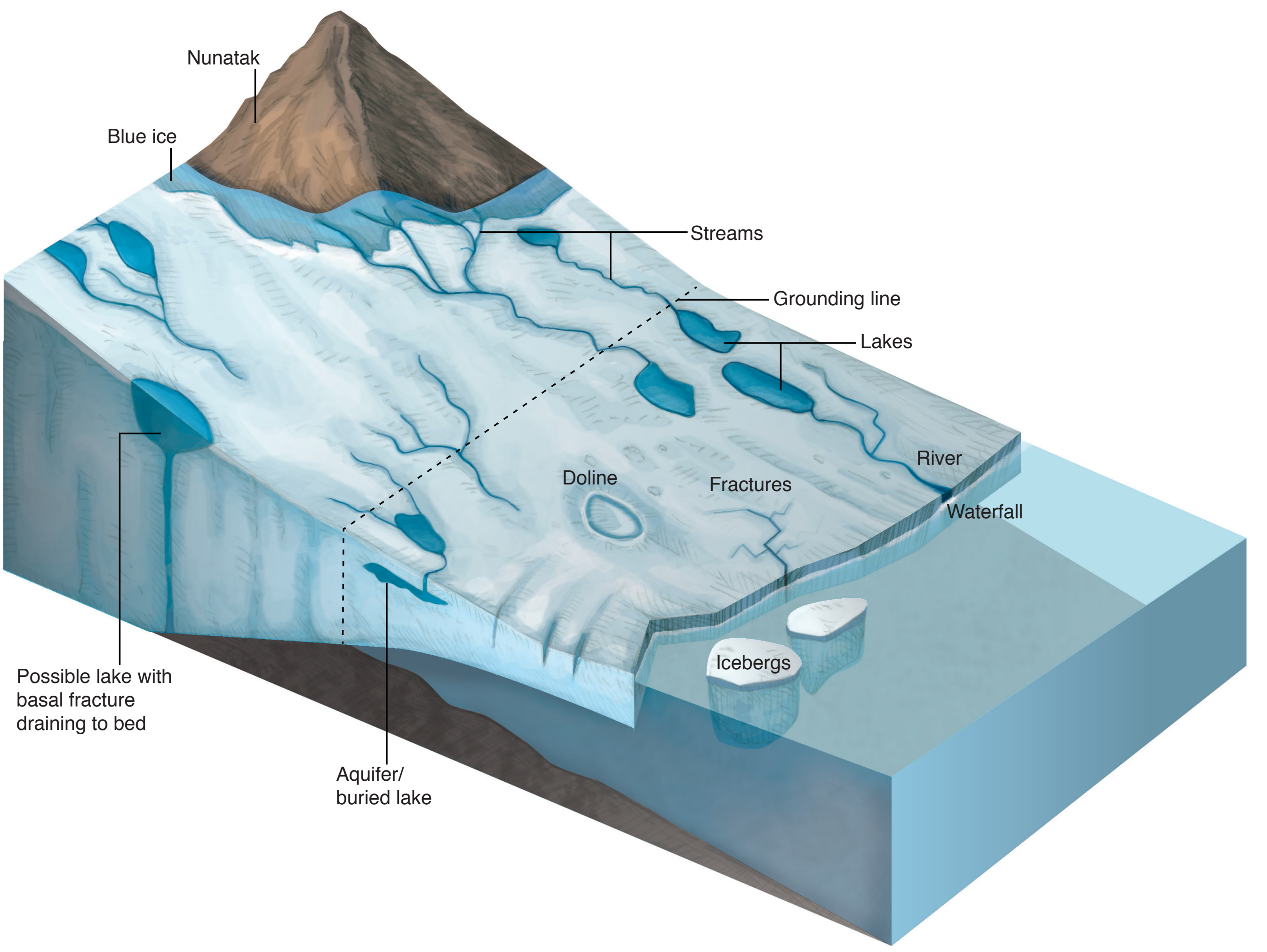


Surface melting and runoff, causing thinning

a

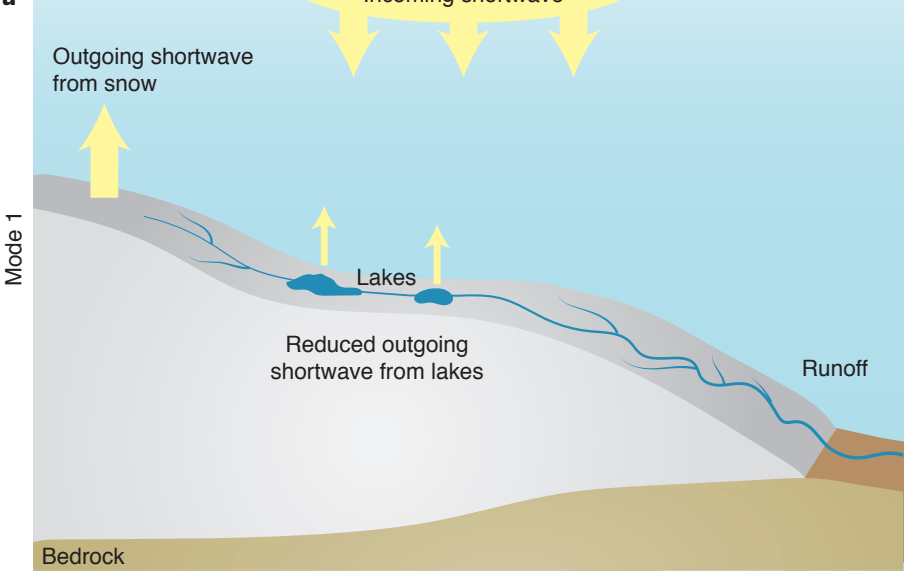

Surface water connected to ice base, increasing ice flow and ocean mixing

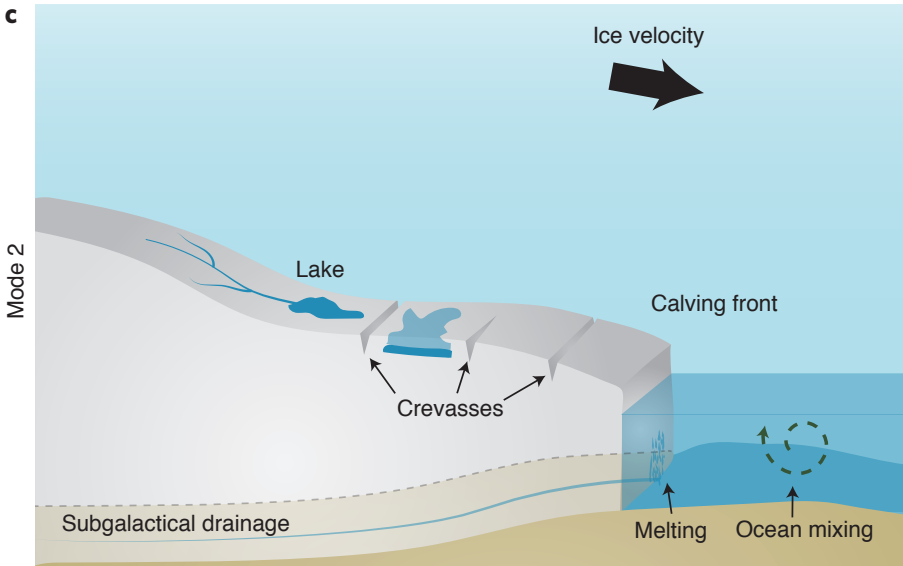

b

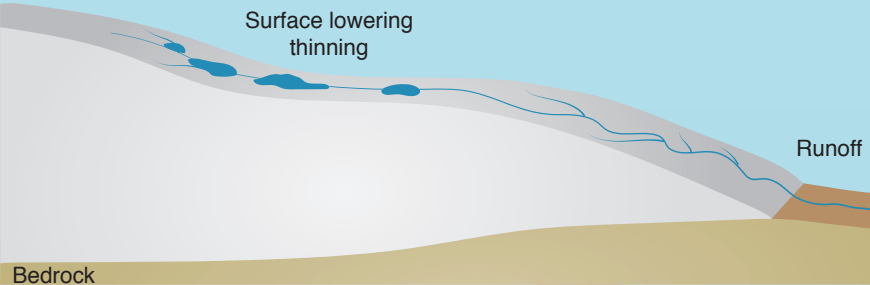

d

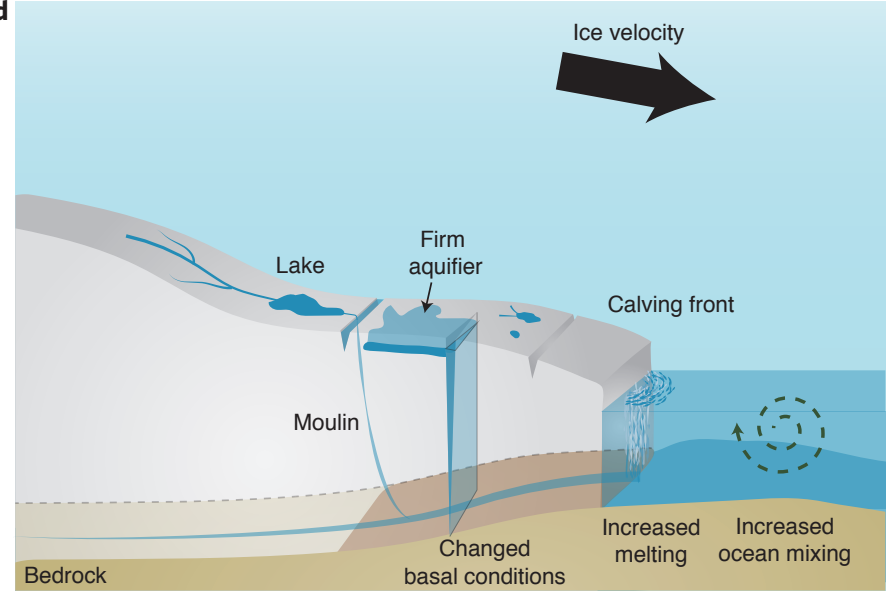

Meltwater loading and hydrofracture, triggering ice shelf collapse

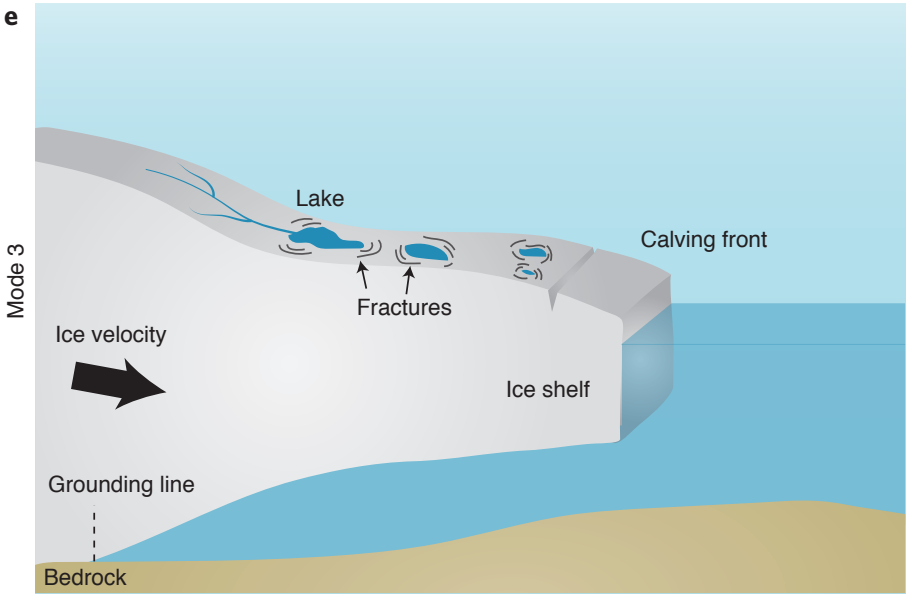

f

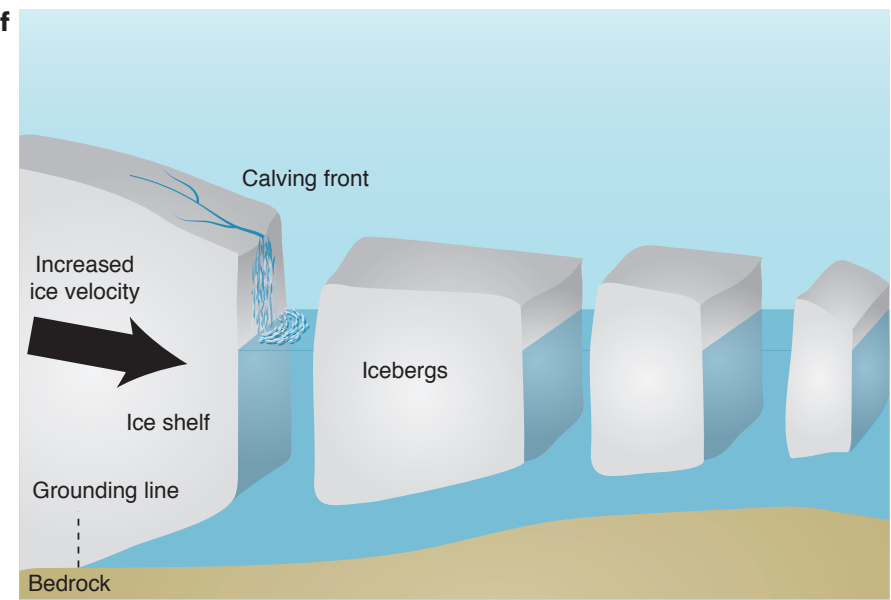


b Antarctica RCP8.5 (2091-2100)

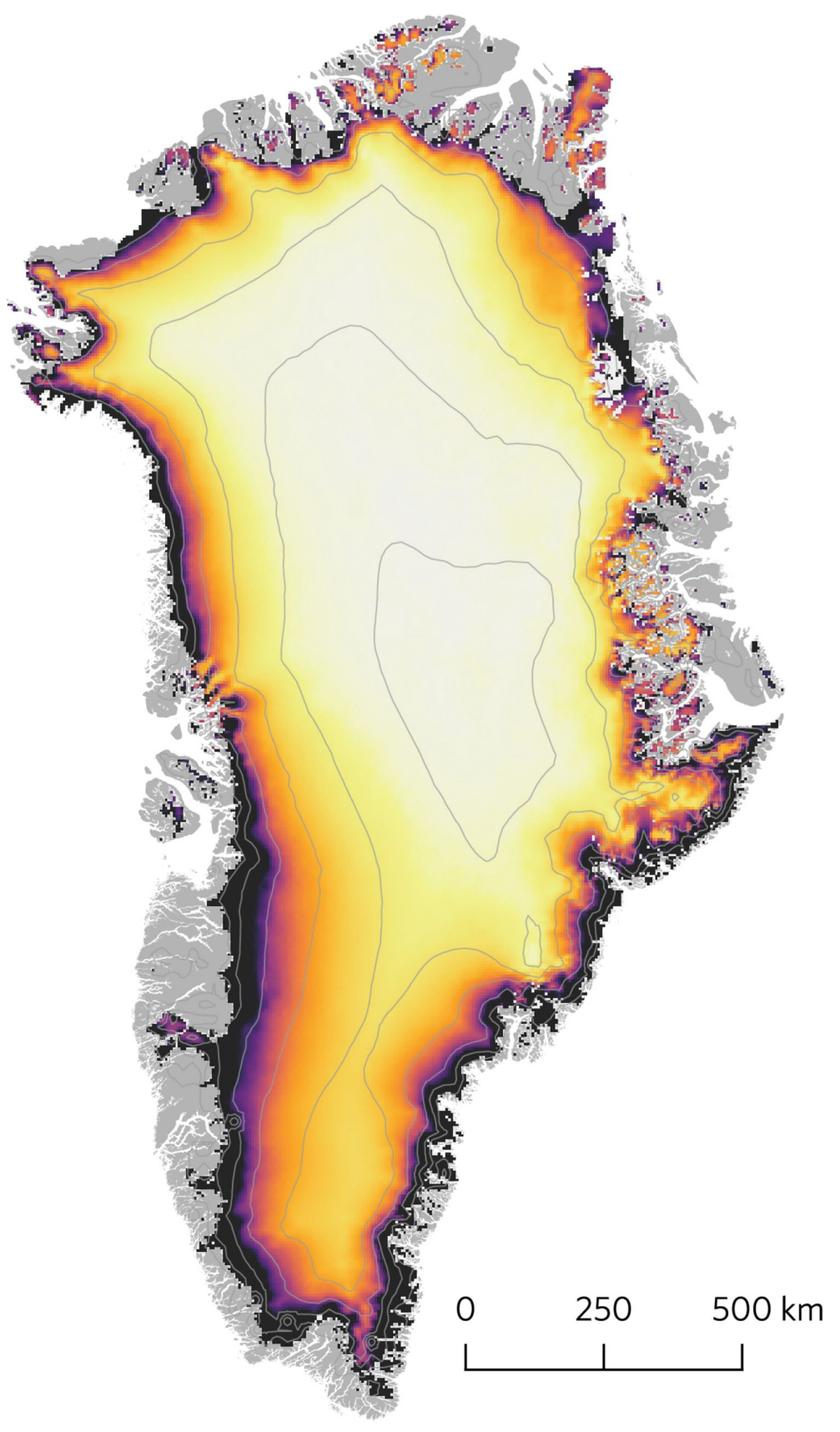

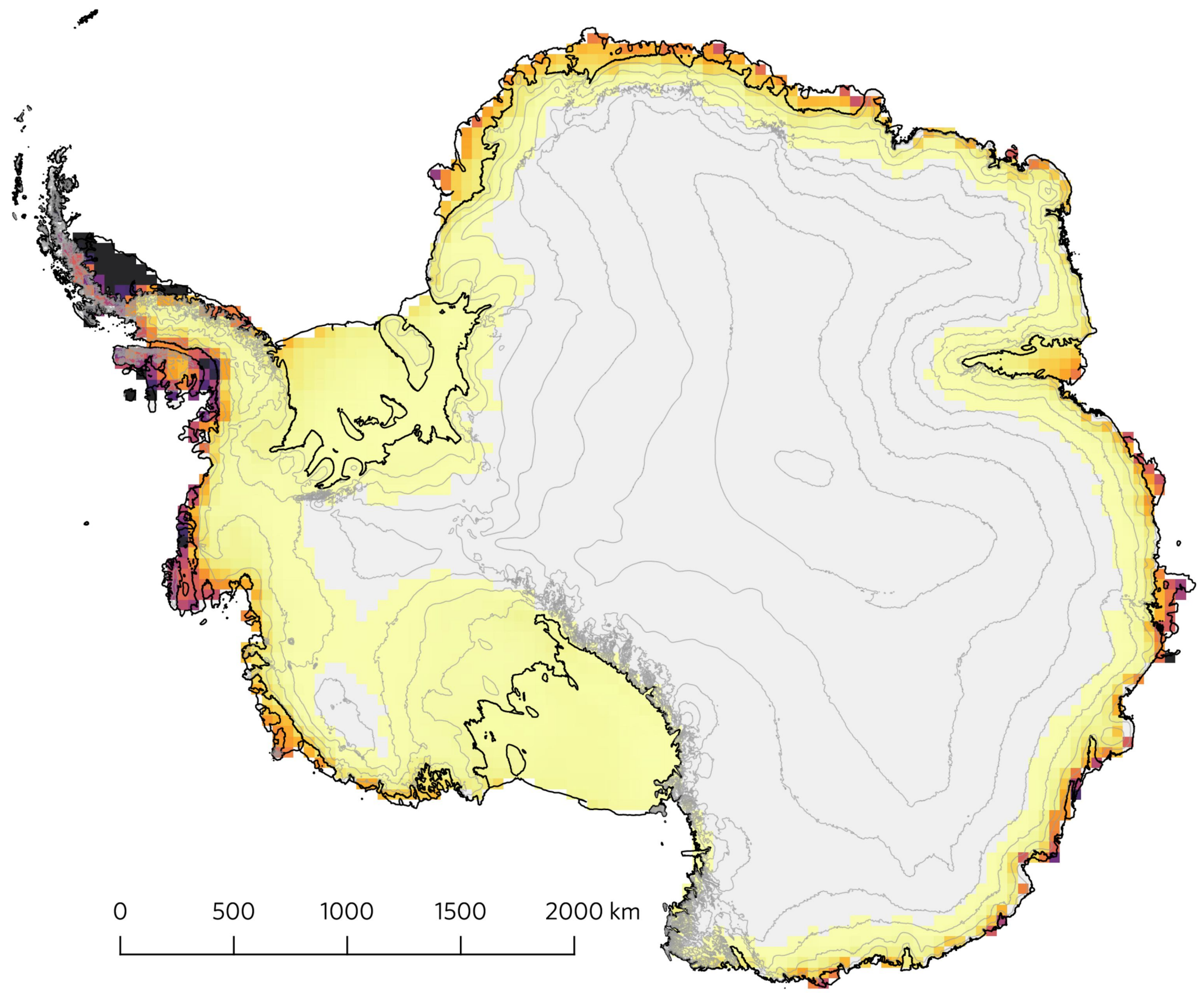

Surface melt ( $m m$ w.e. $\mathrm{yr}^{-1}$ ) 